\title{
PERAMALAN DAN PERENGKINGAN PENJUALAN PRODUK FURNITURE MENGGUNAKAN METODE SINGLE EXPONENTIAL SMOOTHING DAN SAW
}

\author{
Juniko Dwiki Saputro, Setyawan Wibisono \\ Program Studi Teknik Informatika, Fakultas Teknologi Informasi, Universitas Stikubank \\ Jl. Trilomba Juang No 1 Semarang 50241 \\ junikodwiki1@gmail.com, sonny@edu.unisbank.ac.ic
}

\begin{abstract}
In an era of shopping that is more modern and easy in the process of buying a furniture product, it results in an increase in sales of a furniture production. Gudho furniture products are one of the many companies that sell furniture needs in the Semarang area, Central Java. In the unpredictable sale of a product every month, the Gudho company finds it difficult to determine the target product sales each month and it is also difficult to determine the top product for that month. With this sales problem, the Gudho company really needs a sales solution that can predict product sales every month, and determine what type of furniture product can become a top product so that sales of the least products, so the company can make improvements in the quality of sales products on furniture. and benefit the product company. In sales forecasting or bias, it is called forecasting is a method of calculating analysis by carrying out value results in forecasting future events that require past sales data as reference material and using a qualitative or quantitative approach. Forecasting we can use in terms of using a Single Exponential Smoothing method. In addition to predicting the sales data for furniture products, we also carry out the process of ranking the best furniture product sales, calculated using a simple additive weighting (SAW) method. By combining the forecasting method and the product ranking method, it is able to overcome one of the sales problems faced by the Semarang furniture company Guhdo. In the two methods used are created using a website-based display that is built with a PHP programming language and the Codeigniter framework as a program server. So the result of this system is to produce a Support System in sales decisions and sales forecasting with the aim of getting a top product result and sales forecasting for the following month's product.
\end{abstract}

Keywords - Product ranking, SAW, Single Exponential Smoothing, Forecasting.

\begin{abstract}
Abstrak - Dalam era berbelanja yang lebih modern dan mudah dalam mudah dalam proses pembelian suatu produk furniture mengakibatkan peningkatan dalam penjualan sebuah produksi furniture Produk Gudho furniture merupakan satu dari banyak perusahaan yang menjual kebutuhan furniture yang ada di wilayah Semarang. Didalam sebuah produk penjualan yang tidak pasti setiap bulannya, mengakibatkan perusahan Gudho sulit menentukan target penjualan produk setiap bulanya juga sulit menentukan sebuah produk unggulan pada bulan itu.Adanya masalah penjualan tersebut, Gudho sangat memerlukan sebuah solusi penjualan untuk mempermudah meramalkan penjualan produk setiap bulanya, serta menentukan jenis produk furniture apa yang bisa menjadi sebuah produk unggulan sehingga penjualan prouk yang paling sedikit, sehingga perusahaan dapat melakukan perbaikan dalam kualitas produk penjualan pada furniture dan menguntungkan perusahaan produk tersebut. Dalam peramalan penjualan atau bias disebut forecasting adalah sebuah metode analisa perhitungan dengan melakukan hasil nilai dalam perkiraan peristiwa di masa depan yang diperlukan data penjualan masa lalu sebagai bahan referensi dan menggunakan pendekatan kualitatif ataupun juga kuantitatif. Forecasting kita dapat gunakan dalam hal menggunakan sebuah metode Single Exponential Smoothing. Selain di ramalkan data penjualan produk furniture, kita juga melakukan proses perangkingan penjualam produk furniture yang terbaik, dihitung dengan menggunakan sebuah metode simple additive weighting (SAW). Dengan menggabungkan metode forecasting dan metode perangkingan produk tersebut, mampu mengatasi salah satu masalah penjualan yang dihadapi perusahan Guhdo furnitur Semarang. Didalam kedua metode yang digunakan ini dibuat dengan mengunakan framework Codeigniter sebagai sebuah progam server dan tampilan berbasis web yang dibangun dengan sebuah bahasa permrogaman PHP . Maka dari hasil sebuah sistem ini yaitu menghasilkan sebuah Sistem dalam menentukan keputsan penjualan dan perengkingan penjualam dengan sebuah tujuan mendapt sebuah hasil produk terbaik dan melakukan peramalan penjualan produk untuk bulan selanjutnya.
\end{abstract}

Kata Kunci - Perangkingan produk, SAW, Single Exponential Smoothing, Forecasting. 


\section{PENDAHULUAN}

Sektor industri furniture mengalami perkemba ngan yang signifikan dan merupakan penyumbang pajak terbesar kepada negara. Di Indonesia khususnya Kota Semarang, semakin banyak dan muncul para kompetitor baru. Persaingan para pelaku bisnis ini semakin terasa dengan munculnya banyak inovasi terutama dari segi produk dan pemasaran mereka. Revolusi industri 4.0 adalah upaya transformasi dengan mengintegrasikan antara dunia online dengan hampir semua sektor pada perusahaan. Dimana semua proses berjalan dengan internet sebagai penopang utama. Berkat kecanggihan era revolusi industri 4.0 yang mengandalkan kemampuan teknologi sistem cerdas dan otomasi, menjadikan persaingan perusahaan dengan kompetitor menjadi semakin ketat.

GUHDO merupakan salah satu pengembang furniture yang terkemuka di Indonesia yang mempunyai banyak produk di Indonesia. Salah satu produk furniture yang terdapat di Kota Semarang, Jawa Tengah adalah PT. Tandi Tirtamas. PT. Tandi Tirtamas Semarang 5 Ha dengan lokasi site yang sisi barat kota Semarang, Denagn pemasaran yang produk furniture di seluruh wilayah Jawa Tengah. PT. Tandi Tirtamas saat ini memiliki 25 produk furniture dengan berbagai tipe yang ada di produk tersebut. Agar tidak ketinggalan pada era industri 4.0, . PT. Tandi Tirtamas sedang berupaya membangun infrastruktur teknologi dalam membantu proses penjualan. Dengan omzet dan berbagai jenis tipe furniture yang cukup banyak, sehingga data transaksi yang dihasilkan belum dapat diolah secara maksimal untuk kebutuhan sistem manajemen saja. Tidak adanya sistem bantu yang dapat menangkap keperluan dan kebutuhan konsumen akan furniture, membuat developer terus membuat tipe furniture baru yang sesuai dengan intuisi manajemen saja. Padahal jika kita tarik dari laporan penjualan tersebut dan kita olah, dapat juga menghasilkan sistem pendukung keputusan dan membantu perusahaan untuk meningkatkan kualitas produk dan omzet perusahaan.

Dari masalah tersebut, tentunya perlu sebuah solusi atau gagasan baru yang dapat mengatasi masalah dalam mengelola transaksi penjualan furnitur yang sekaligus dapat meramalkan dan merangkingkan penjualan produk furniture yang terbaik. Sehingga target penjualan pada periode yang akan datang dapat ditentukan oleh perusahaan. Salah satu solusi yang dirasa cukup tepat dan efektif dalam mengatasi masalah diatas yaitu sistem informasi peramalan dan perangkingan penjualan produk furnaitur yang berbasis website. Dengan semakin berkembangnya teknologi informasi dizaman sekarang ini, website dirasa cukup tepat untuk membantu proses olah data dan proses perangkingan serta peramalan penjualan yang dibangun dengan metode SAW dan Single Exponential Smoothing
Pada penelitian sebelumnya pernah melakukan beberapa pembahasan mengenai sebuah metode Simple additive weifhting pada sebuah system pendukung keputusan pada pencarian sebuah property yang dilakukan oleh.

[1]. Menurut Penelitian Aandianto Sistem Perengkingan tersebut menghasilkan subah system yang dapat berguna dalam memberkan alternatif kepada sebuah customer dalam memilih sebuah perumahan yang sesuai dengan kebutuhan customer saat ini.[2]. Menurut Penelitihan Ratih Sistem Perengkingan tersebut mengasilkan sebuah system yang berguna untuk mengasilka sebuah perengkingan produk yang paling laris dipasaran

Simple additive weighting ini sering digunakan sebagai salah satu cara dalam pengambilan keputusan dengan suatu metode penjumlahan terbobot. Sebelum dibandingkan dengan mengunakan metode rating untuk semua hasil yang alternatif, terlebih dahulu melakukan sebuah proses perhitungan normalisasi matriks dalam keputusan (X) pada nilai rasio tertentu. Dalam mengunakan metode SAW ini banyak sekali digunakan dalam persoalan Multi-Attribute Decision Making (MADM) untuk mendapatkan hasil alternatif yang paling baik untuk berbagai hasil alternatif mengunakan atribut tertentu.

Dalam menyelesaikan permasalahan tersebut kita mengunakan sebuah metode yang mendaptakan beberapa tahapan yang sangat diperlu diantara adalah:

1. Langkah awal adalah penentuan sebuah atribut dari kriteriasebagai refrensi pengambilan keputusan yaitu $\mathrm{Ci}$

2. Kemudian dari tiap kriteria yang telah dibuat sebelumnya, akan ditentukan nilai rating kecocokannya.

3. Lalu membuat perhitungan matriks dalam mengambil keputusan yang mendapat beberapa kriteria yang dibuat menjadi (Ci), setelah melakukan perhitungan yang perlu dilakukan normalisasi matriks untuk nilai berdasarkan hasil dalam persamaan yang menyesuwekan dengan beberapa jenis atribut (baik itu sebuah atribut cost atau subuah benefit) sehingga mendapatkan nilai matriks yang ternormalisasi nilai $\mathrm{R}$.

4. Sebuah hasil nilai perangkingan dari sebuah alternatif diperole mengunakan cara penjumlahan dari sebuah hasil perkalian martiks $\mathrm{R}$ mengunakan nilai bobot kriteria. nilai paling tinggi akan dipilih sebagai alternatif (Ai) solusi dari suatu permasalahan.

Berikut adalah sebuah perhitungan dengan metode yang menghasilkan nilai formula perhitungsn untuk mendapatkan hasil nilai normalisasinya adalah:

\section{A. Sistem Perengkingan}




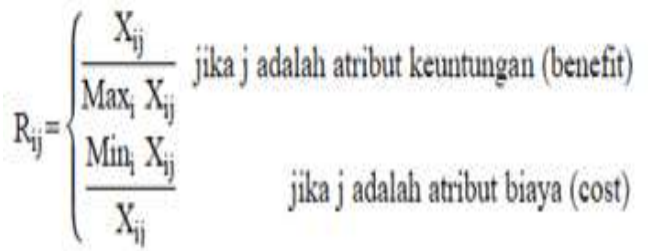

Dimana:

$\mathrm{Rij}=$ rating kinerja ternormalisasi

Maxij = nilai maksimum dari setiap baris dan kolom

Minij = nilai minimum dari setiap baris dan kolom

$\mathrm{Xij}=$ baris dan kolom dari matriks

Dengan rij adalah rating kinerja ternormalisasi dari alternatif $\mathrm{Ai}$ pada atribut $\mathrm{Cj}$; $\mathrm{i}=1,2, \ldots \mathrm{m}$ dan $\mathrm{j}=$ $1,2, \ldots, \mathrm{n}$.

\section{B. Forecasting}

[3]. Menurut Penerlitian Agustinawati pada system Forecating tersebut menghasilkan sebuah system aplikasi yang dapat meramal pendaftaran perserta mahasiswa yang baru yang inin mendaftar di perguruan.

[4]. Menurut Penelitian Salman padasistem Forecasting tersebut enghasilkan sebuah system peramlan dalam penjualan gamis yang ada ditoko tersebut.

Metode Peramalan dengan mengunakan sebuah metode single exponential smoothing atau biasa disebut juga metode penghalusan eksponensial tunggal adalah sebuah metode yang mengunakan suatu prosedur secara perhitunganya dilakukan terus menerus untuk memperbaiki sebuah peramalan yang merata rata (menghaluskan $=$ smoothing $)$ didapat nilai masalalu suatu data yang menghasilkan nilai runtut waktu mengunakan cara menurun (eksponensial). Karaker dalam metode ini adalah :

1) Setiap data yang didapat dianalisis dengan sifat deret waktu.

2) Pengunaan data sesuai untuk data yang diperoleh berpola horisontal.

3) Setiap data menggunakan nilai bobot yang berbeda untuk setiap data yang dihasilakn masa lalu, dimana nilai bobot yang dihasilkan menurun secara eksponensial setia nilai pengamatan yang dihasikan paling baru sampai mendaptakan nilai pengamatan yang paling lama.

Kekurangan dari mengunakan metode ini adalah

1) Dalam menentukan tingkat akurasi nilai yang dihasilkan dalam mengunakan metode ini yaitu perhitungan nilai masih terlalu rendah.

2) Dalam mengunakan metode pemulusan eksponensial ini nilai yang di dapata bernilai tunggal tidak cukup baik dalam penerapanya jika sebuah data yang bersifat tidak stasioner, karena nilai dalam persamaan ini yaitu digunakan dalam mengunakan sebuah metode eksponensial tunggal yang tidak terdapat prosedur nilai pemulusan dalam pengaruh tren yang berakibat dengan data tidak stasioner menjadi tetap tidak stasioner.

Dalam pengunaan rumus pada pengunaan metode single exponential smoothing rumus yang dipakai yaitu:

$$
\mathrm{Ft}+1=\alpha \mathrm{Xt}+(1-\alpha) \mathrm{Ft}-1
$$

Dimana:

$\mathrm{Ft}+1=$ Ramalan untuk periode ke $\mathrm{t}+1$

$\mathrm{Xt}=$ Nilai riil periode ke $\mathrm{t}$

$\alpha \quad=$ Bobot yang menunjukkan konstanta penghalus $0 \leq \leq 1)$

Ft-1 = Ramalan untuk periode ke $\mathrm{t}-1$

\section{METODE PENELITIAN}

Ruang Lingkup Penelitian Dalam penelitian ini yang menjadiobjek untuk penulis yaitu sebuah perusahaan PT. Tandi Tirtamas, yang beralamat di Jl. Bambankerep, Kec. Ngaliyan, Kota Semarang. ,Dalam Penelitian ini penulis berkonsentrasi pada mata kuliah teknik informatika.

\section{Jenis dan Sumber Data}

Adapun beberapa jenis data yang digunakan dalam melakukan penelitian ini adalah:

1. Data kualitatif merupakan data yang tidak dapat diukur dalam skala numericData kualitatif yang akan digunakan dalam penelitian ini mempunyai gambaran umum perusahaan PT. Tandi Tirtamas mulai dari ,teori-teori, hasil wawancara dan informasi yang relevan dalam penelitian ini.

2. Data kuantitatif

merupakan data yang dapat diukur dalam skala numeric Data kuantitatif ini yang digunakan dalam sebuah penelitian yaitu berupa sebuah data penjualan perusahaan PT. Tandi Tirtamas pada bulan Januari 2019 sampai Desember 2019.

Sumber data yang akan digunakan dalam penelitian ini adalah:

1. Menggunakan Data Primer merupakan data yang diperoleh dengan melakukan survey lapangan yang menggunakan semua metode pengumpulan dataoriginal.Sumber data yang digunakan dalam penelitian ini adalah mengunakan obsevasi dan wawancara.

2. Menggunakan Data Sekunder merupakan sebuah data yang telah dikumpulkan oleh lembaga pengumpulan data yang telah dipublikasikan kepadamasyarakat untuk pengguna data Sumber data sekunder yang dipakai dalam penelitian ini adalah bukubuku dan jurnal.

\section{Metode Pengumpulan Data}

Dalam pengumpulan data Metode yang kital akukandengan 3 cara, yaitu: 
1. Penelitian Lapangan

a. Observasi yaitu sebuah teknik pengumpulan data yang mempunyai ciri yang spesifik bila dibandingkan dengan teknik yang lain Dalam hal ini, peneliti dalam melakukan pengumpulan data menyatakan terus terang kepada sumber data, bahwa ia sedang melakukan penelitian. Jadi mereka yang diteliti mengetahui sejak awal sampai akhir tentang aktivitas peneliti.

b. Wawancara merupakan sebuah teknik pengumpulan data apabila peneliti ingin melakukan sebuah studi pendahuluan untuk menemukan permasalahan yang diteliti, dan juga untuk mengetahui hal-hal dari responden yang lebih mndalam.

2. Studi literatur merupakan identifikasi, lokasi, dan analisis dari dokumen yang berisi informasi yang berhubungan dengan permasalahan penelitian secara sistematis. Data yang digunakan dalam penelitian ini seperti buku-buku yang ada di perpustakaan Universitas Unisbank, dan jurnal.

\section{Metode Analisis Data}

Dalam Metode analisis data yang digunakandalam penelitian ini yaitu analisis statistic deskriptif.statistic deskriptif adalah statistik yang digunakan untuk menganalisa datadengan cara mendeskripsikan atau menggambarkan sebuah data yang telah diterkumpul sebagaimana yang ada tanpa bermaksud membuat kesimpulan yang berlaku untuk umum atau generalisasi. Teknik analisis kuantitatif dalampenelitian ini mengunakan metode single eksponensial smoothing dalam peramalan pejualan dan metode Simple additive weighting (SAW) dalam perengkingan penjualan produk furnethur.

\section{HASIL DAN PEMBAHASAN}

Pada pembahasan ini terhadap beberapa hasil penelitian.dan pengujian yang didapat dan disajikan dalam sebuah bentuk tampilan program. Hasil percobaan ditampilkan dalam program yang berisi hasil perhitungan perangkingan danzperamalan untuk periode selanjutnya. Implementasi program terhadap Sistem Perangkingan Produk Dengan Menggunakan Sebuah Metode SAW dan Peramalan Penjualan dengan Metode Single Exponential Smoothing, pada tampilan dari program tersebut adalah sebagai berikut:

\section{A. Rancangan System}

\section{Halaman Login Sistem}

Halaman login digunakan sebagai autentikasi pengguna yang sah untuk masuk kedalam sistem, pengguna akan dimintai username dan password yang sudah terdaftar pada sistem untuk login masuk.

\section{Menu Utama}

Pada menu utama ini merupakan hasil tampilan awal sebuah sistem, ketika pengguna membuka sistem maka akan tampil halaman beranda dan ucapan selamat datang kepada pengguna yang telah masuk ke sistem. Berikut implementasi tampilan dari menu utama sistem perangkingan dan peramalan produk furnetur PT. Tandi Tirtamas Semarang.

\section{Menu Data Kategori Furnetur}

Setelah masuk ke sistem, pengguna bisa mulai mendata jenis atau kategori Furnetur yang akan di pasarkan di perusahaan PT. Tandi Tirtamas Semarang. Sehingga setiap produk furnetur yang dijual akan memiliki jenisnya masing - masing dan memudahkan pengguna dalam mendata penjualan furnetur.

\section{Menu Data Furnetur}

Setelah mendata kategori atau jenis - jenis furnetur, selanjutnya pengguna dapat memasukan data utama furnetur yang akan dijual di perusahaan

\section{Menu Input Data Penjualan}

Pada tampilan menu input ini data dari penjualan digunakan dalam menginput hasil penjualan produk, dalam menu ini pengguna dapat mengelola penjualan tiap produknya. Selain itu, pengguna juga dapat melihat rekapan penjualan dari hari - hari yang telah lalu.

\section{Menu Laporan Perangkingan}

Menu laporan perangkingan ini berfungsi untuk melihat rekap perangkingan produk paling laku menggunakan metode SAW. Dalam perangkingan ini, diurutkan produk terbaik berdasarkan kriteria yang telah di tentukan sebelumnya. Tiap produk akan dihitung menggunakan rumus yang telah tersedia dan di masukan ke dalam sistem, kemudian tiap - tiap produk akan mendapatkan nilai masing - masing, nilai tersebut yang akan menentukan hasil perangkingan produk terbaik.

\section{Menu Laporan Peramalan}

Dalam Tampilan menu laporan ini dalam peramalan berfungsi menampilkan sebuah laporan peramalan penjualan produk. Dari produk yang telah dirangkingkan, kemudian produk tersebut diramalkan penjualannya selama 1 tahun kedepan berdasarkan data penjualan di tahun sebelumnya. Perhitungan peramalan menggunakan metode Single Exponential Smothing . Data yang ditampilkan dalam menu ini yaitu hasil penjualan di tahun sebelumnya, dan peramalan di tahun yang 
akan datang. Sehingga pengguna dapat membandingkan antara hasil penjualan dan ramalan penjualannya.

\section{B. Proses perhitungan dalam System}

Dalam proses ini kita akan melakukan sebuah proses perhitungan dalam sestem tersebut dengan mengunakan dua buah metode perhitungan SAW dan Single Exponential Smothing dengan proses perhitungan sebagai berikut.

\section{Perhitungan Perangkingan}

Proses perangkingan dengan metode SAW perhitungannya cukup mendetail dan lengkap. Sebelum melakukan perangkingan, terlebih dulu harus di tetapkan kriteria sebagai acuan perangkingan. Berikut contoh rumus dan laporan perhitungan perangkingan metode SAW.

Tabel 1. Kriteria Perangkingan

\begin{tabular}{|l|c|c|}
\hline \multicolumn{1}{|c|}{ Kriteria } & Atribute & Nilai \\
\hline Jumlah Penjualan (CO1) & benefit & 5 \\
\hline Tipe Produk (C02) & benefit & 3 \\
\hline Ukuran Produk (C03) & benefit & 3 \\
\hline Fasilitas Produk (C04) & benefit & 3 \\
\hline Bonus Pembelian Produk (C05) & benefit & 2 \\
\hline Pembuatan Produk & benefit & 3 \\
\hline Harga & cost & 4 \\
\hline
\end{tabular}

Nilai diatas didapatkan melalui kesepakatan dengan pengguna. Setelah didapatkan nilai diatas, maka selanjutnya menyiapkan data alternatif atau data penjualan yang akan di rangkingkan. Berikut beberapa contoh penjualan yang diambil dari sample data perusahaan Gudho Semarang.

Tabel 2. Data Alternatif

\begin{tabular}{|l|l|}
\hline Nama produk & Kode Produk \\
\hline DIamon & $\mathrm{A} 01$ \\
\hline Tokyo & $\mathrm{A} 02$ \\
\hline Viktorian & $\mathrm{A} 03$ \\
\hline
\end{tabular}

Selanjutnya data diatas diolah dan dilakukan penilaian ini dari beberapa kriteria yang dapat ditentukan. Dengan beberapa penilaian yang dilakukan dengan melihat laporan nyata milik perusahaan sebagai pembanding pemberian nilai. Pemberian nilai bisa dalam skala $0-5$, dimana setiap produk wajib diberi nilai meskipun angkanya nol (0).
Tabel 3. Penjualan dan Nilai Produk

\begin{tabular}{|l|r|r|r|r|r|r|r|}
\hline Kode & C01 & $\mathrm{C} 02$ & $\mathrm{C} 03$ & $\mathrm{C} 04$ & $\mathrm{C} 05$ & $\mathrm{C} 06$ & $\begin{array}{l}\text { C07 } \\
\text { (juta) }\end{array}$ \\
\hline $\mathrm{A} 01$ & 6 & 100 & 80 & 2 & 4 & 4 & 320 \\
\hline$A 02$ & 4 & 140 & 130 & 4 & 3 & 4 & 1600 \\
\hline$A 03$ & 4 & 120 & 100 & 4 & 3 & 4 & 1400 \\
\hline
\end{tabular}

Langkah selanjutnya yaitu melakukan normalisasi nilai, dari nilai yang telah didapatkan di tabel sebelumnya. Berikut hasil perhitungannya.

1. Mencari sebuah nilai dari table $\mathrm{C} 01$

$\mathrm{r}_{11}=6 / \max (6 ; 4 ; 4)=6 / 6=1$

$\mathrm{r}_{21}=4 / \max (6 ; 4 ; 4)=4 / 6=0,66$

$r_{31}=4 / \max (6 ; 4 ; 4)=4 / 6=0,66$

2. Mencari sebuah nilai dari table $\mathrm{C} 02$

$\mathrm{r}_{12}=100 / \max (100 ; 140 ; 120)=100 / 140=0,71$

$\mathrm{r}_{22}=140 / \max (100 ; 140 ; 120)=140 / 140=1$

$r_{32}=120 / \max (100 ; 140 ; 120)=120 / 140=0,85$

3. Mencari sebuah nilai dari table $\mathrm{C} 03$

$\mathrm{r}_{13}=80 / \max (80 ; 130 ; 100)=80 / 130=0.61$

$\mathrm{r}_{23}=130 / \max (80 ; 130 ; 100)=130 / 130=1$

$\mathrm{r}_{33}=100 / \max (80 ; 130 ; 100)=100 / 130=0.76$

4. Mencari sebuah nilai dari table $\mathrm{C} 04$

$\mathrm{r}_{14}=2 / \max (2 ; 4 ; 4)=2 / 4=0,5$

$\mathrm{r}_{24}=4 / \max (2 ; 4 ; 4)=4 / 4=1$

$\mathrm{r}_{34}=4 / \max (2 ; 4 ; 4)=4 / 4=1$

5. Mencari sebuah nilai dari table $\mathrm{C} 05$

$\mathrm{r}_{15}=4 / \max (4 ; 3 ; 3)=4 / 4=1$

$\mathrm{r}_{25}=3 / \max (4 ; 3 ; 3)=3 / 4=0,75$

$\mathrm{r}_{35}=3 / \max (4 ; 3 ; 3)=3 / 4=0,75$

6. Mencari sebuah nilai dari table $\mathrm{C} 06$

$\mathrm{r}_{16}=4 / \max (4 ; 4 ; 4)=4 / 4=1$

$\mathrm{r}_{26}=4 / \max (4 ; 4 ; 4)=4 / 4=1$

$r_{36}=4 / \max (4 ; 4 ; 4)=4 / 4=1$

7. Dan yang terakhir Mencari sebuah nilai dari table C07

$\mathrm{r}_{17}=\min (320 ; 1600 ; 1400) / 320=320 / 320=1$

$\mathrm{r}_{27}=\min (320 ; 1600 ; 1400) / 1600=320 / 1600=0,2$

$r_{37}=\min (320 ; 1600 ; 1400) / 1400=320 / 1400=0,22$

Setelah itu kita gabungkan dari setiap nilai di dalam table C1 sampai C7 menghasilkan

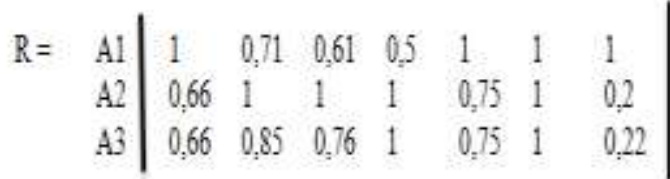


Tabel 4 Normalisasi Nilai

\begin{tabular}{|l|l|l|l|l|l|l|l|}
\hline Kode & C1 & C2 & C3 & C4 & C5 & C6 & C7 \\
\hline A01 & 1 & 0.71 & 0.61 & 0.5 & 1 & 1 & 1 \\
\hline A02 & 0.66 & 1 & 1 & 1 & 0.75 & 1 & 0.2 \\
\hline A03 & 0.66 & 0.85 & 0.76 & 1 & 0.75 & 1 & 0.22 \\
\hline
\end{tabular}

Setelah menghitung normalisasi nilai, terakhir bisa didapatkan nilai akhir dari perangkingan produk paling laku. Tabel perangkingan produknya yaitu sebagai berikut.

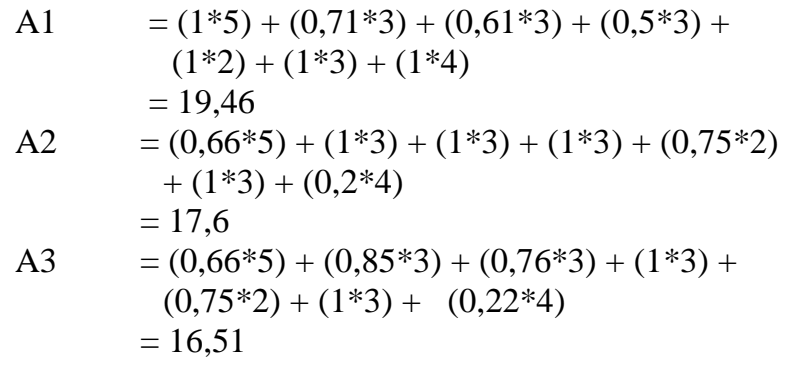

Tabel 5. Hasil Total Perangkingan

\begin{tabular}{|l|c|}
\hline Kode Produk & Total Nilai Perangkingan \\
\hline A01 & 19,46 \\
\hline A02 & 17,6 \\
\hline A03 & 16,51 \\
\hline
\end{tabular}

Dari tabel diatas bisa disimpulkan bahwa produk dengan kode A01 merupakan produk paling laku, hal ini didapat karena produk A01 memiliki nilai akhir paling tinggi yaitu 19,46. Sedangkan produk A03 berada diurutan paling akhir dengan nilai akhir 16,51.

\section{Perhitungan Peramalan}

Proses perhitungan peramalan Single Exponential Smoothing, Dari produk yang telah dirangkingkan diatas, dicari nilai penjualannya lalu di ramalkan penjualannya untuk periode yang akan datang.

Tabel 3.6. Penjualan

\begin{tabular}{|c|l|c|}
\hline No & \multicolumn{1}{|c|}{ Bulan } & Penjualan \\
\hline 1. & Januari & 80 \\
\hline 2. & Februari & 96 \\
\hline 3. & Maret & 66 \\
\hline 4. & April & 50 \\
\hline 5. & Mei & 78 \\
\hline 6. & Juni & 55 \\
\hline 7. & Juli & 68 \\
\hline 8. & Augustus & 88 \\
\hline 9. & September & 75 \\
\hline 10. & Oktober & 85 \\
\hline 11. & November & 65 \\
\hline 12. & Desember & 80 \\
\hline
\end{tabular}

Nilai diatas kemudian diramalkan menggunakan Single Exponential Smoothing, dengan menghitung rata - rata dari bulan sebelumnya. Berikut proses perhitungan menggunakan metode Single Exponential Smoothing,

A. Proses pertama dalam melakukan sebuah peramalan ini, nilai dari alpha $(\alpha)$ yang akan dilakukan ujicoba (trial) secara acak bebrapa nilai bobot dengan contoh perhitungan ini adalah $(\alpha=0.1)$ Berikut ini merupakan sebuah perhitungan untuk mendapatkan nilai konstanta alpha $(\alpha=0.1) \mathrm{F} 1=$ Karena pada nini ini saat $\mathrm{t}=1$ nilai F1 (peramalan pada periode pertama) belum bisa tersedia, maka untuk itu perlu mengatasi permasalah ini dapat dilakukan dengan cara menetapkan nilai pada F1 sama dengan nilai data pada periode pertama (X1) sebesar 80 :

B. Perhitungan Peramalan Peiode Febuari

$$
\begin{aligned}
\mathrm{F} 2 & =\alpha \mathrm{X} 1+(1-\alpha) \mathrm{F} 1 \\
& =(0.1 * 96)+(1-0.1) 80 \\
& =9.6+(0.9) 80 \\
& =9.6+72 \\
& =81.6
\end{aligned}
$$

Pada perhitungan nilai peramalan (forecasting) pada proses ini nilai pertama tidak dihitungkan karena nilai ini untuk menghitung data peramalan (forecasting) membutuhkan sebuah hasil perhitungan dimana at (1) dan bt (1) pada perhitungan ini periode yang sebelumnya yaitu periode pada bulan Januari 2019 . Sedangkan dalam pada proses pertama pada periode bulan Januari ini tidak dilakukan perhitungan sehingga perhitungan pada nilai at (1) dan bt (1) pada periode Januari 2019 masih kosong.

C Pada proses perhitungan kedua nilai dari F2 pada perhitungan ini terdap nilai periode sebelumnya yaitu pada bulan Februari sehingga diketahui nilai tersebut, sehingga niliai ini kita dapat gunakan hasil perhitungan dari pada nilai F2 untuk menghitung dari nilai F3 pada periode bulan Maret. Berikut merupakan perhitungan dari peramalan pada periode bulan Maret 2019

$$
\begin{aligned}
\mathrm{F} 3 & =\alpha \mathrm{X} 1+(1-\alpha) \mathrm{F} 1 \\
& =(0.1 * 66)+(1-0.1) 81.6 \\
& =6.6+(0.9) 81.6 \\
& =6.6+73.44 \\
& =80.04
\end{aligned}
$$

D. Pada proses tahap ketiga yaitu melakukan proses pada peramalan (forecast) pada periode perhitungan ke 4 yaitu pada periode bulan April 2019 berdasarkan nilai yang di dapat pada data periode bulan sebelumnya yang sudah memperoleh nilai proses perhitungan yaitu periode bulan Maret 2019. Untuk menghitung nilai peramalan (forecast) pada periode bulan April 2019 ini dibutuhkan sebuah hasil perhitungan yang perhitungan pada periode sebelumnya yaitu periode bulan Maret 2019. Berikut ini merupakan sebuah hasil nilai perhitungan forecast pada periode bulan April 2019: 


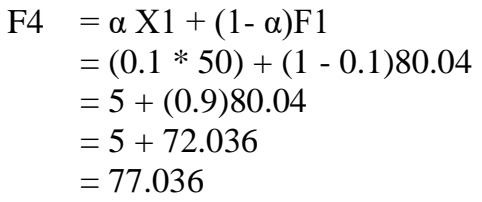

E. Peroses selanjutnya menhitung hasil (forecast) Pada periode sebelumnya hinga mengasilkan data peramlah dalam periode satu tahun, dengan perhitungan lengkap data nilai yang dihasilkan yaitu.

$$
\begin{aligned}
\mathrm{F} 5 & =\alpha \mathrm{X} 1+(1-\alpha) \mathrm{F} 1 \\
& =(0.1 * 78)+(1-0.1) 77.036 \\
& =7.8+(0.9) 77.036 \\
& =7.8+69.33 \\
& =77.13 \\
\mathrm{~F} 6 & =\alpha \mathrm{X} 1+(1-\alpha) \mathrm{F} 1 \\
& =(0.1 * 55)+(1-0.1) 77.13 \\
& =5.5+(0.9) 77.13 \\
& =5.5+69.41 \\
& =74.91 \\
\mathrm{~F} 7 & =\alpha \mathrm{X} 1+(1-\alpha) \mathrm{F} 1 \\
& =(0.1 * 68)+(1-0.1) 74.91 \\
& =6.8+(0.9) 74.91 \\
& =6.8+67.41 \\
& =74.41 \\
\mathrm{~F} 8 & =\alpha \mathrm{X} 1+(1-\alpha) \mathrm{F} 1 \\
& =(0.1 * 88)+(1-0.1) 74.91 \\
& =8.8+(0.9) 74.91 \\
& =8.8+67.41 \\
& =(0.1 * 80)+(1-0.1) 75.77 \\
& =8+(0.9) 75.77 \\
& =8+68.19 \\
& =76.19 \\
\mathrm{~F} 11 & =\alpha \mathrm{X} 1+(1-\alpha) \mathrm{F} 1 \\
& =(0.1 * 65)+(1-0.1) 76.97 \\
& =6.5+(0.9) 76.97 \\
& =6.5+69.27 \\
& =75.77 \\
& =(0.1 * 75)+(1-0.1) 76.21 \\
& =7.5+(0.9) 76.21 \\
& =7.5+68.58 \\
& =76.0 .8 \\
& =(0.1 * 85)+(1-0.1) 76.08 \\
& =8.5+(0.9) 76.08 \\
& =8.5+68.47 \\
& =76.97 \\
& \\
& \\
& \\
& \\
& \\
&
\end{aligned}
$$

Data tersebut kemudian disajikan didalam tabel peramalan penjualan untuk periode 1 tahun kedepan. Hasil perhitungannya yaitu terdapa pada tabel yang ada di bawah ini.

Tabel 3.7 Penjualan

\begin{tabular}{|c|c|c|c|}
\hline No & Bulan & $\begin{array}{c}\text { Penjualan } \\
2019\end{array}$ & $\begin{array}{c}\text { Penjualan } \\
2020\end{array}$ \\
\hline 1. & Januari & 80 & 76.19 \\
\hline 2. & Februari & 96 & 81.6 \\
\hline 3. & Maret & 66 & 80.04 \\
\hline 4. & April & 50 & 77.03 \\
\hline 5. & Mei & 78 & 77.13 \\
\hline 6. & Juni & 55 & 74.91 \\
\hline 7. & Juli & 68 & 74.21 \\
\hline 8. & Agustus & 88 & 75.58 \\
\hline 9. & September & 75 & 75.52 \\
\hline 10. & Oktober & 85 & 76.46 \\
\hline 11. & November & 65 & 75.31 \\
\hline 12. & Desember & 80 & 75.77 \\
\hline
\end{tabular}

\section{Mengembangkan Sistem Berbasis WEB}

Pada pengembangan sebuah sistem ini dimulai dengan membuat sebuah pemodelan yang berorientasi pada objek dengan menggunakan UML. Berikut ini komponen-komponen dari UML yaitu.

\section{Use Case Diagram}

Pada perancangan model ini pengunaan diagramnya dengan use case diagaram pada mulai proses menggambarkan perilaku pada penggunaan sebuah sistem yang dibuat. Didalam sistem tersebut terdapat beberapa sistem pendukung keputusan yang peneliti buat, sehingga terdapat dua buah aktor yang memerankanya pada system ini yaitu Admin dan Master admin yang terdapat pada gambar 1 berikut.

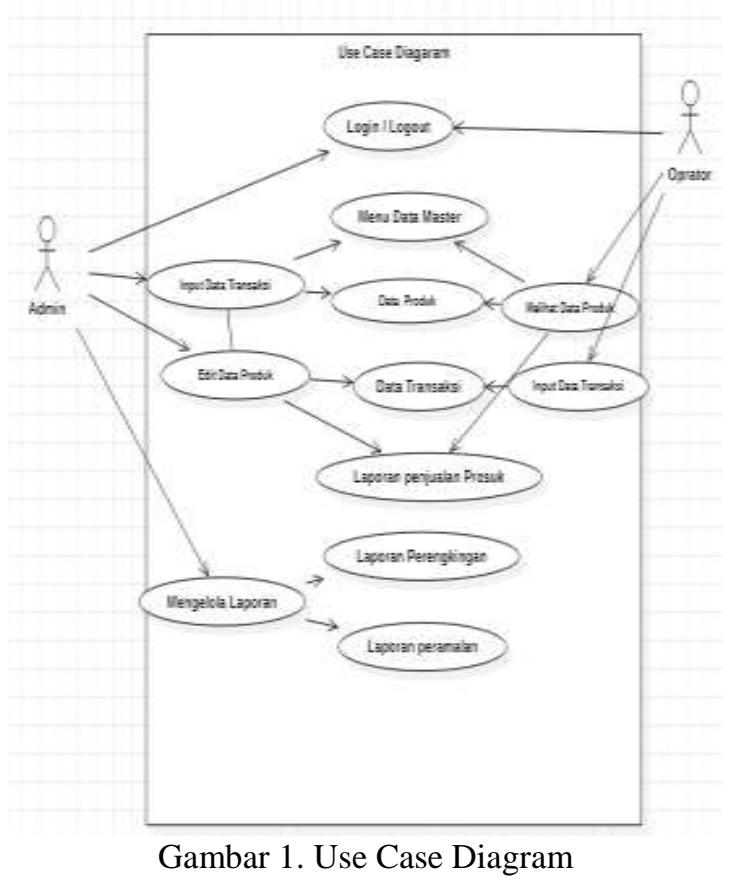


Pada gambar 1 ini use case diagram pada aktor masteradmin dapat mengakses keseluruhan menu pada sistem keseluruhan case. Pada admin dapat mengakses Data Produk, Data transaksi, dan Laporan penjualan.

\section{Activity Diagram}

Pada proses ini penggunaan pada sistem masingmasing system setiap aktor pada use case dapat dijelaskan pada activity diagram berikut.

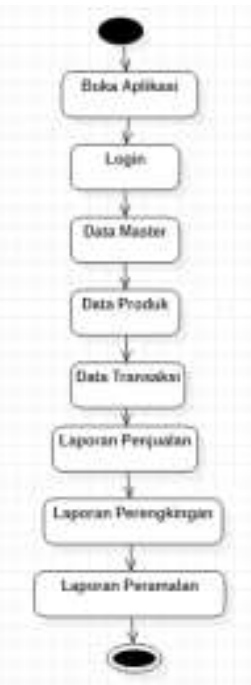

Gambar 2. Activity Diagram Admin

Pada gambar 2. di atas ini merupakan gambaran system untuk alur pada setiap langkah pada sistem bagi pengguna dalam menggunakan sistem.

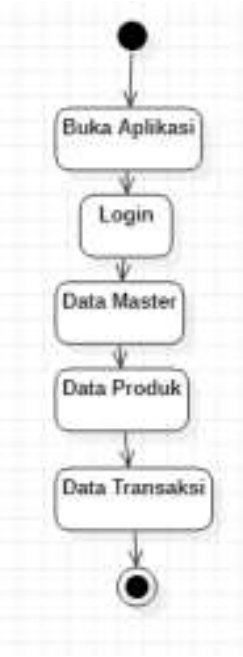

Gambar 3. Activity Diagram Oprator

Pada gambar 3. menunjukkan setiap alur yang digunakan dalam setiap proses langkah demi langkah bagi admin dalam penggunaan sebuah sistem.

\section{Squensial Diagram}

Dalam hal ini menggambarkan setiap rangkaian pada system pesan yang dapat digunakan pada squensial diagram, berikut sequensial diagram pada sistem.

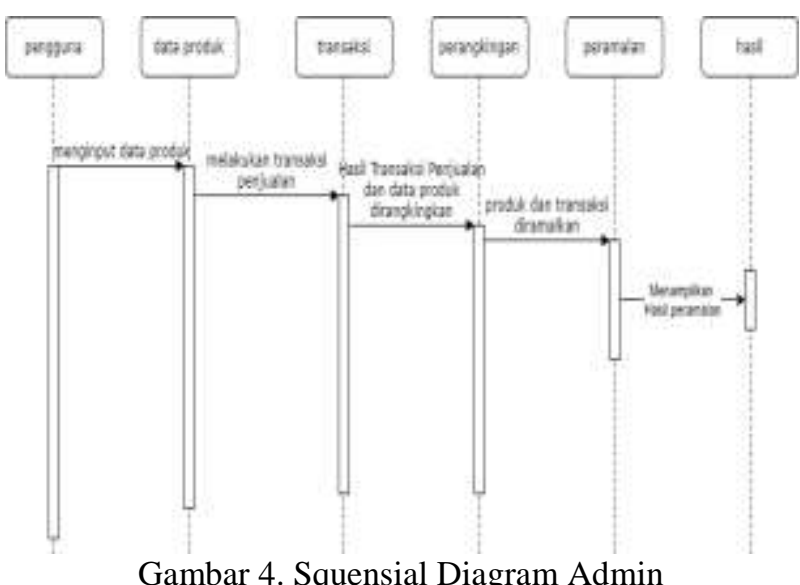

Dari gambar 4. di atas terdapat Master adminhal pertama yangdilakukan adalah mengakses menu home dengan cara membuat terlebih dahulu aplikasi. Setelah itu bisa menambah kondisi yang sesuai dengan data yang diteliti. Setiap kondisi akan diberi nilai inputan untuk memperoleh hasil nilai perhitungan. Sedangkan untuk squensial diagram pada admin terlihat pada gambar 5. berikut.

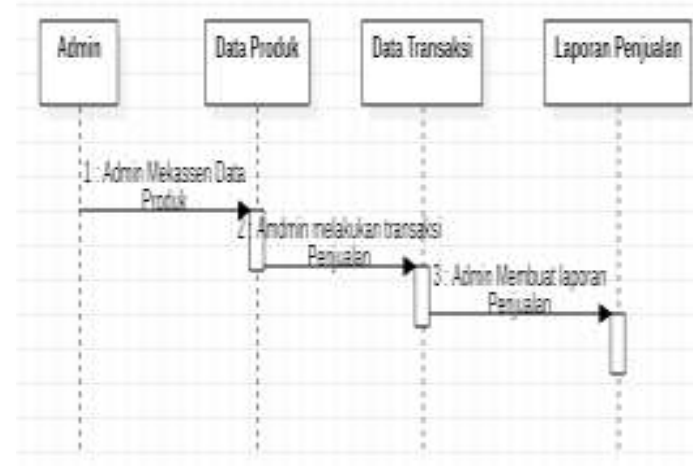

Gambar 5. Squensial Diagram Oprator

Pada gambar 5 ini terlihat setiap alisan pesan akses pada sistem yang dilakukan oleh admin. 


\section{Class Diagram}

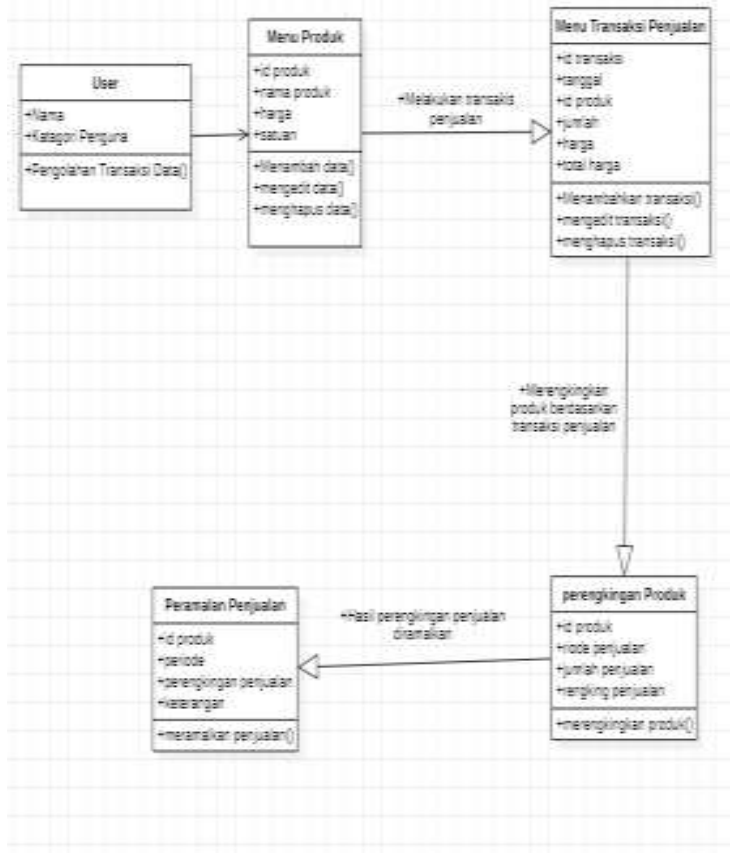

Gambar 6. Class Diagram

\section{Implementasi Pada Aplikasi Berbasis WEB}

Dalam melakukan implementasi pada aplikasi ini dapat dilihat data sebagai berikut yaitu.

1. Halaman Login

Pada halaman login ini kita dapat gunakan untuk mengakses menu utama pada sebuah sistem masuk ke sebuah sistem dengan mengisi kolom pada username dan password agar dapat masuk kedalam form utama

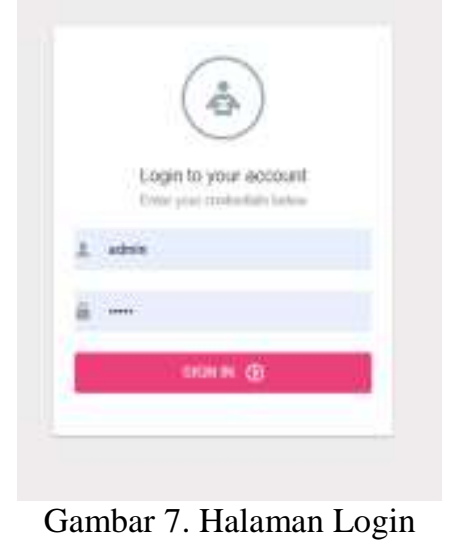

Pada gambar 7 menjelaskan bahwa sistem akan memanggil function cekuser yang digunakan untuk mengecek kode admin dan password yang dimasukkan oleh admin atau masteradmin, jika kode admin dan password valid maka akan ditampilkan halaman index.php sedangkan jika tidak valid maka akan ditampilkan pesan kode admin atau password salah dan kembali ke halaman login serta menghapus session login.

\section{Halaman Menu Data Produk}

Berdasarkan implementasi perancangan halaman data produk. Tampilan Halaman data barang digunakan untuk memproses penambahan, mengubah, dan menghapus data barang yang di perusahaan Gudho semarang. Dan berikut tampilan dari menu data barang..

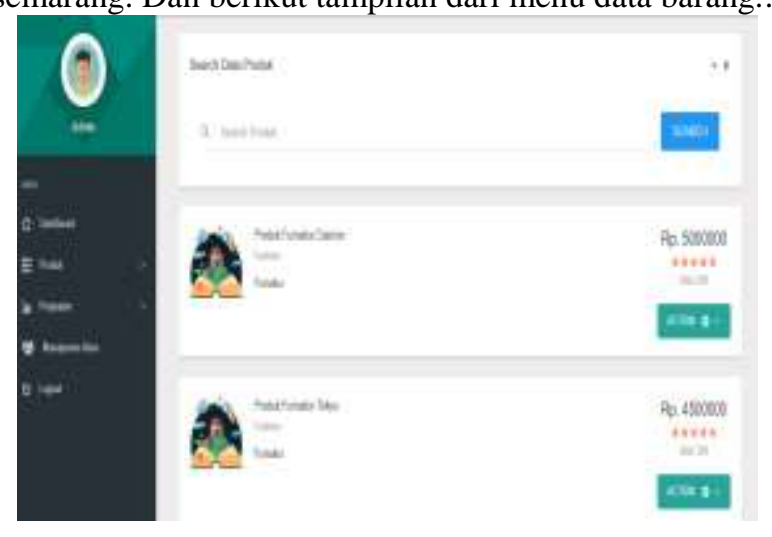

Gambar 8. Halaman Data Produk

Tampilan diatas memperlihatkan data produk yang sudah tersedia dan terdaftar di sistem ini. Data diatas menampilkan gambar furnaitur, kode furnaitur, nama furnaitur, harga, ukuran dan skor penjualan. Data diatas dapat di edit dan dihapus oleh pengguna jika ada perubahan baik dari spesifikasi maupun harga. Pengguna juga dapat menambahkan data furnaitur jika dikemudian hari ada tambahan tipe atau jenis furnaitur yang akan dipasarkan, cara untuk menambahkan data furnaitur bisa di klik tombol aktor yang ada di pojok kanan tabel, lalu akan muncul form tambah furnatur baru.

3. Halaman Menu Transaksi Penjualan Produk

Halaman Transaksi Penjualan Produk digunakan untuk melakukan penjualan seluruh produk yang dijual di produk guhdo semarang. menjelaskan bahwa pada system dimana menu foam penjualan menampilkan keseluruhan transasi penjualan yang dilakukan di gudho semarang disini kita bias lihat harga barang dan nama barang yang di transaksi.

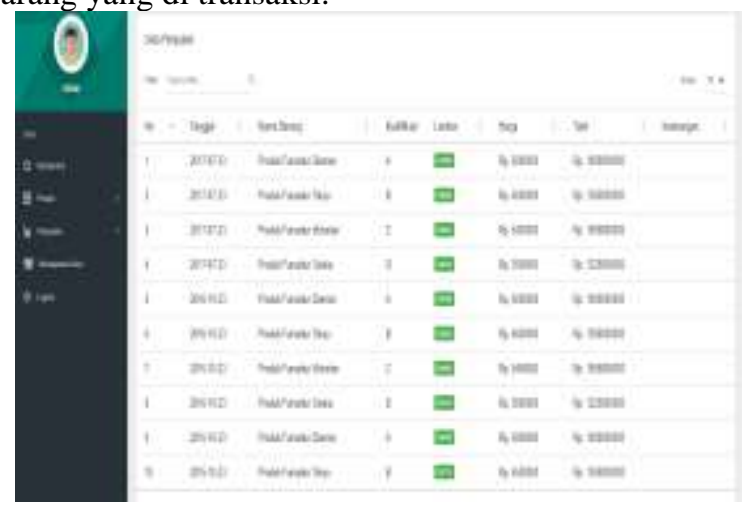

Gambar 9. Menu Transaksi 


\section{Menu Laporan Penjualan}

menjelaskan bahwa pada system dimana menu foam laporan penjualan menampilkan keseluruhan laporan transasi penjualan yang dilakukan di gudho semarang disini kita bias menambahkan setiap laporan penjualan yang terbaru yang dihasilkan dari harga barang dan nama barang yang di transaksi..
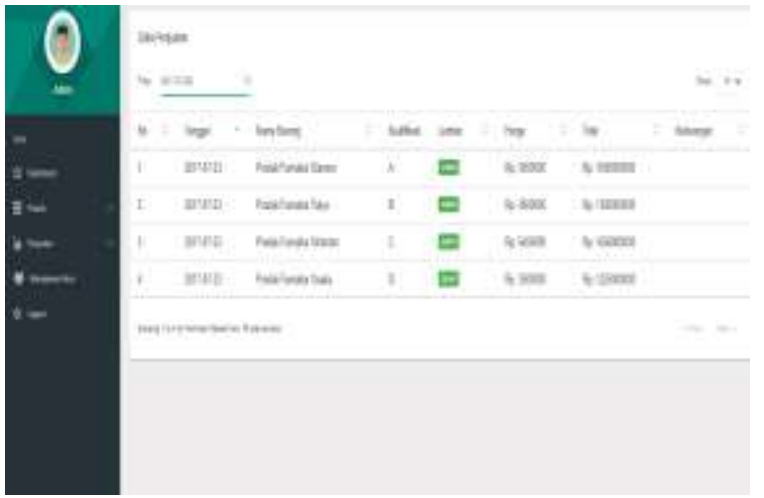

Gambar 10. Menu Laporan Penjualan

\section{Menu Laporan Perangkingan Produk}

Pada Menu halaman ini kita dapat digunakan untuk melihat semua laporan pada perangkingan yang telah dilakukan perhitungan oleh sistem berdasarkan data kriteria yang ada. Pengguna dapat memasukan tanggal atau periode tanggal untuk melihat perangkingan produk yang ada. Berikut tampilan laporan perangkingan produk menggunakan metode SAW.

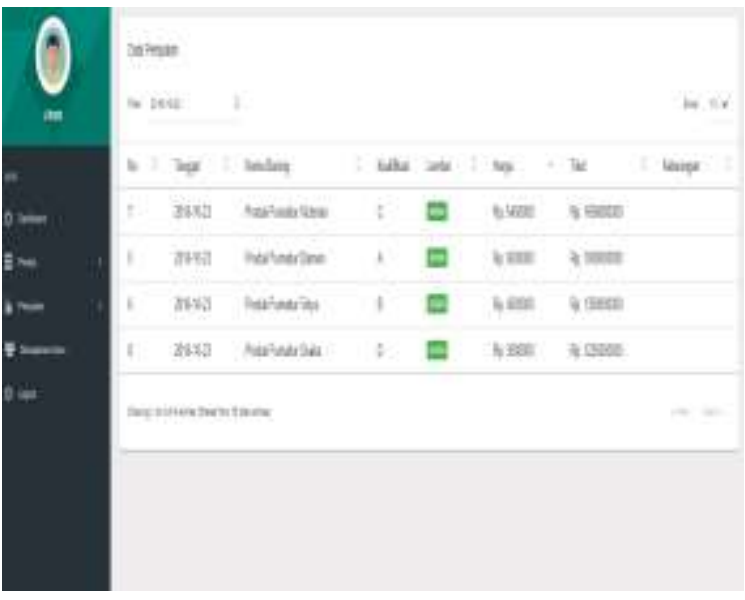

Gambar 11. Menu Halaman Perengkingan

Gambar diatas merupakan tampilan data alternatif penjualan produk. Data diatas sudah mendapatkan nilai masing - masing berdasarkan kriteria yang telah ditentukan oleh pengguna. Sehingga tiap produk mendapatkan nilai .Setalah mendapatkan data alternatif, produk kemudian dilakukan analisa nilai masing masing untuk mendapatkan nilai yang lebih akurat.

6. Halaman Laporan Peramalan Produk

Dari hasil perangkingan produk, lalu data tersebut dilakukan peramalan penjualan produkdalam hal diproses yang digunakan adalah metot Single Exponential Smoothing.

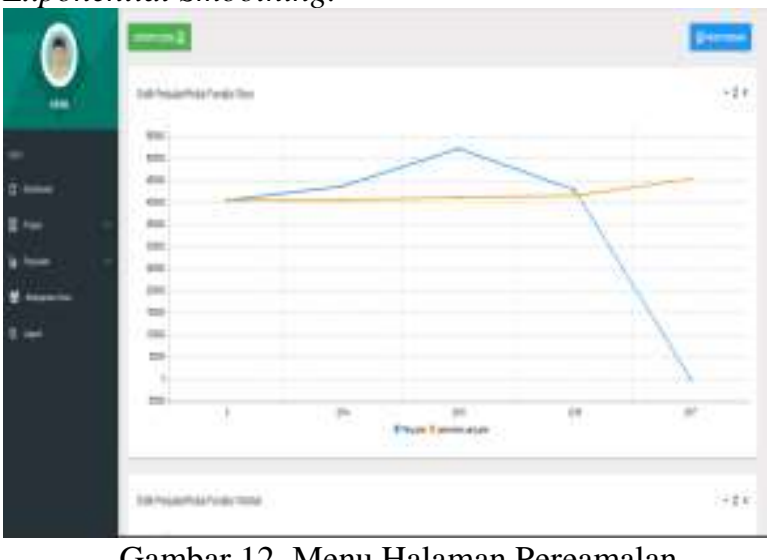

Gambar 12. Menu Halaman Pereamalan

Dimana data yang didapat dari penjualan ditampilkan pada halam menu ini merupakan dari hasil penjualan pada satu tahun sebelumnya dan satu tahun yang akan datang, sehingga pengguna dapat membandingkan data penjualan asli dan data peramalan penjualan di tahun yang akan datang. Hasil dari peramalan ini terdapat jumlah nilai penjualan yang di dapat dilihat pada gambar dibawah ini yaitu.

\section{KESIMPULAN}

Berdasarkan Hasil dari penelitian ini, terdapat data implementasi dan pengujian pada sistem, maka dapat diambil kesimpulan sebagai berikut :

Perangkingan pada sebuah produk furnitur menggunakan metode yang baik yaitu metode SAW karena dapat menghasilkan urutan hasil penjualan yang terbaik yang telah dilakukan oleh perusahaan gudho.. Perangkingan ini dilakukan dengan menggunakan kriteria - kriteria yang telah disepakati dan dinilai berdasarkan kriteria yang di tetapkan oleh perusahaan. Sehingga tiap - tiap produk furnitur yang dijual mendapatkan nilai masing - masing. Dari kriteria yang ada, tersebut terbagi menjadi dua jenis yaitu cost dan benefit, dimana cost yaitu jika semakin rendah nilainya maka semakin baik. Sedangkan benefit yaitu semakin tinggi nilainya semakin baik.

Setelah melakukan perangkingan pada produk furniture tersebut, juga dilakukan peramalan penjualan (forecasting) untuk hasil penjualan dalam satu tahun kedepan. peramalan dilakukan dengan menggunakan metode Single Exponential Smothing, yaitu metode peramalan yang dimana perhitungan peramalan nya dilakukan dengan melihat data dari satu bulan sebelumnya.

Dengan adanya hasil pada sistem ini, diharapkan dapat membantu proses transaksi dan penjualan perusahaan dalam menjual produk furnitur, juga membantu perusahaan dalam menentukan target 
penjualan di tahun yang akan datang. Sehingga perusahaan bisa memperoleh gambaran jumlah produk yang akan terjual di tahun yang akan datang.

\section{DAFTAR PUSTAKA}

[1] Andianto, Tomy Reza. Sistem Pendukung Keputusan Pemilihan Rumah Tinggal Di Perumahan Menggunakan Metode Simple Additive Weighting (SAW) (Studi Kasus : Kota Samarinda), Prosiding Seminar Ilmu Komputer dan Teknologi Informasi. Vol. 2 (1). Samarinda. 2017.. 197 - 201.

[2] Sugiarto, Hari. Penerapan Metode Simple Additive Weighting Untuk Pemilihan Rumah, Indonesian Jurnal on Computer and Information Technology. Vol. 1 (1). Mei 2016. pp. 96 - 103.

[3] Ariyanto, Rudy, Penerapan Metode Double Exponential Smoothing Pada Peramalan Produksi Tanaman Pangan, Jurnal Informatika Polinema. ISSN: 2407-070X. Vol. 4 (1). 2017. pp. $57-62$.

[4] W. Handoko, "Prediksi Jumlah Penerimaan Mahasiswa Baru Dengan Metode Single Exponential Smoothing (Studi Kasus: AMIK Royal Kisaran)," JURTEKSI (Jurnal Teknol. dan Sist. Informasi), vol. V, no. 2, , 2019 pp. 125-132

[5] A. Agusta and S. N. Anwar, "Aplikasi Forecasting Penjualan Dengan Metode Single Exponential Smoothing (Studi Kasus : Optik Nusantara)," Proceeding SINTAK 2019, 2019. pp. 278-281,

[6] S. Mallu, "Sistem Pendukung Keputusan Penentuan Karyawan Kontrak Menjadi Karyawan Tetap Menggunakan Metode SAW", Jurnal Ilmiah Teknologi Informasi Terapan, STMIK Profesional, ISSN : 2407 - 3911, 2016.

[7] L. Utari and N. Triyanto, "Prediksi Jumlah Produksi Mobil pada Perusahaan Karoseri dengan Menggunakan Metode Exponential Smoothing," J. Ilm. Teknol. - Inf. dan Sains, vol. 7, no. 1, 2017. pp. 59-67,

[8] Makridakis, S., Steven C Wheelwright., Victor E Mc.Gee. Metode dan Aplikasi Peramalan. Jilid 1. Edisi Revisi. Binarupa Aksara : Jakarta. 2003.

[9] D. Anggoro and W. Wulandari, "Forecasting Demand Dengan Metode Single Exponential Smoothing Untuk Analisa Jumlah Penjualan Obat Ternak," Simp. Nas. Ilm. dengan tema (Peningkatan Kualitas Publ. Ilm. melalui Has. Ris. dan Pengabdi. Kpd. Masyarakat), no. November, pp. 551-560, 2019, doi: 10.30998/simponi.v0i0.300.

[10] Mukhyi,M.A..2008Forecasting. URL:http://www. mukhyi.staff.gunadarma.ac.id/Downloads/file s/9309/FORECASTING.pdf. Diakses pada tanggal 15 Mei 2020.

[11]M. A. Maricar, "Analisa Perbandingan Nilai Akurasi Moving Average dan Exponential Smoothing untuk Sistem Peramalan Pendapatan pada Perusahaan XYZ," J. Sist. dan Inform., vol. 13,no.2,pp.3645,2019. 